\title{
TESTING AND VALIDATION OF DRIS FOR APPLE TREE
}

\author{
Gilmar Ribeiro Nachtigall ${ }^{1 *}$; Antonio Roque Dechen² \\ ${ }^{1}$ Embrapa Uva e Vinho, C.P. 130 - 95700-000 - Bento Gonçalves, RS - Brasil. \\ ${ }^{2}$ USP/ESALQ - Depto. de Ciência do Solos, C.P. 9 - 13418-900 - Piracicaba, SP - Brasil. \\ *Corresponding author <gilmar@cnpuv.embrapa.br>
}

\begin{abstract}
To evaluate three procedures of the calculation of DRIS indices, as well as the efficiency of DRIS as a method for the interpretation of apple tree leaf analyses. This study uses data collected in apple producing areas of the Rio Grande do Sul and Santa Catarina States, Brazil. The concentrations of nitrogen, phosphorus, potassium, calcium, magnesium, boron, copper, iron, manganese, and zinc were determined in the leaf samples. The validation of the DRIS method used results of an experiment of potassium fertilization. The DRIS indices were calculated using two criteria for the choice of the ratio order of nutrients ( $F$ value - ratio of variance of the relationships among nutrients between the reference group and the low productivity group, and $\mathrm{R}$ value - correlation coefficients between the productivity and the relationship between pairs of nutrients) and three forms of calculation of nutrient functions (methods of Beaufils, Jones and Elwali \& Gascho). The Nutritional Balance Index (NBI) presented negative correlation with the productivity in all combinations. The DRIS method described by Elwali \& Gascho, using the F value, presented a performance similar to the criterion of sufficiency range, and it can be used for the interpretation of foliar analysis of apple trees, because it presents values of the nutritional balance index that indicates the nutritional status of the plants, and for the efficiency in the nutritional diagnosis of the crop.
\end{abstract}

Key words: Malus Domestica, foliar diagnosis, nutritional balance

\section{CALIBRAÇÃO E VALIDAÇÃO DO DRIS PARAMACIEIRA}

\begin{abstract}
RESUMO: Este trabalho teve por objetivo avaliar três procedimentos de cálculo dos índices DRIS, bem como avaliar a eficiência do DRIS como método de interpretação de resultados de análises de folhas de plantas de macieira. O estudo foi realizado nas regiões produtoras de maçã do Rio Grande do Sul e de Santa Catarina. Foram determinadas as concentrações de nitrogênio, fósforo, potássio, cálcio, magnésio, boro, cobre, ferro, manganês e zinco nas amostras de folhas. A validação do método DRIS utilizou resultados de um experimento de adubação potássica. Os índices DRIS foram calculados utilizando-se dois critérios para a escolha da ordem da razão dos nutrientes (valor "F" razão de variância das relações entre nutrientes entre o grupo de referência e de baixa produtividade e valor "R" - coeficientes de correlação entre os valores de produtividade e a relação entre os pares de nutrientes) e três formas de cálculo das funções dos nutrientes (métodos de Beaufils, Jones e Elwali \& Gascho). O Índice de Balanço Nutricional (IBN) apresentou correlação negativa e significativa com a produtividade em todas as combinações de métodos testados. O método DRIS descrito por Elwali \& Gascho, utilizando o "valor F", apresentou desempenho semelhante ao critério de faixa de suficiência e pode ser utilizado para a interpretação da análise foliar em macieira, por apresentar valores de IBN que indicam o estado nutricional das plantas e pela eficiência no diagnóstico nutricional da cultura.
\end{abstract}

Palavras-chave: Malus Domestica, diagnose foliar, equilíbrio nutricional

\section{INTRODUCTION}

Foliar diagnosis, based on standardized methods of sampling, is the most effective criterion in the evaluation of the nutritional status of fruitful plants (Faust, 1989). This methodology, however, presents some practical limitations: i) it does not allow the interpretation of the results of samples collected out of the suitable period; ii) the result of the foliar analysis, even if accomplished in a short period of time, does not allow to correct nutritional problems for the same harvest. 
The Diagnosis and Recommendation Integrated System (DRIS) is a method of nutritional diagnosis of plants based on an index calculation for each nutrient, considering its relation with the other nutrients, and comparing each relation with average relations of a reference population (Beaufils, 1971). The original equation of Beaufils (1973) generates DRIS indices enhancing the most deficient nutrients. From the methodology of Beaufils (1973), several modifications in the form of calculation of the DRIS indices were proposed. The equation of Jones (1981) is characterized by involving simpler calculations and it uses the reverse of the standard deviation to consider the variability of the relation. The equation of Elwali \& Gascho (1984) consists of a modification of the method proposed by Beaufils (1973), in that a limit of tolerance is used to consider two balanced nutrients.

There are few studies with the DRIS method for the apple tree crop, although some results have been obtained in Canada (Parent \& Granger, 1989), in Hungary (Szücs et al., 1990; Szücs \& Kállay, 1990), in New Zealand (Goh \& Malakouti, 1992), and in India (Singh et al., 2000). In all of these studies, DRIS was considered appropriate for the nutritional diagnosis of the crop. In Brazil, there are no studies on the use of this method for the nutritional diagnosis of the apple tree.

The aim of this study was to evaluate three calculation procedures of DRIS indices, as well as to verify the efficiency of DRIS as method to interpret results of leaf analyses of apple tree plants, in relation to the method of nutritional diagnosis, based on the criterion of sufficiency range, now used in South Brazil.

\section{MATERIAL AND METHODS}

The research was carried out in the apple producing area of Campos de Cima da Serra (28 30 'S and $\left.50^{\circ} 56^{\prime} \mathrm{W}\right)$; , in the Rio Grande do Sul State, and in the areas of Alto Vale do Rio do Peixe $\left(27^{\circ} 01^{\prime} \mathrm{S}\right.$ and $\left.50^{\circ} 55^{\prime} \mathrm{W}\right)$ and Planalto Serrano $\left(28^{\circ} 17^{\prime} \mathrm{S}\right.$ and $49^{\circ} 56^{\prime} \mathrm{W}$ ), in the Santa Catarina State. The predominant soils in these areas are the Humic Xanthic Hapludox and Tipic Hapumbrept. The methodology used for the collection of the samples, for the accomplished analytical determinations and for the establishment of the DRIS norms for the apple tree crop is described in Nachtigall \& Dechen (2007).

For the choice of the ratio order of nutrients two criteria were used, one called $\mathrm{R}$ value (Nick, 1998), and another called F value (Letzsch, 1985 and Walworth \& Summer, 1987). The DRIS indices for the nutrients were calculated by the procedures pro- posed by Beaufils (1973), Elwali \& Gascho (1984) and Jones (1981), obtaining the DRIS index $\mathrm{I}_{\mathrm{A}}$, for nutrient $\mathrm{A}$ in the following way:

$$
\begin{aligned}
& \text { m n } \\
& \sum \mathrm{f}\left(\mathrm{A} / \mathrm{B}_{\mathrm{i}}\right)-\sum \mathrm{f}\left(\mathrm{B}_{\mathrm{j}} / \mathrm{A}\right) \\
& \mathrm{I}_{\mathrm{A}}=\frac{\mathrm{i}=1 \quad \mathrm{j}=1}{\mathrm{~m}+\mathrm{n}}
\end{aligned}
$$

Beaufils (1973):

$$
f(A / B)= \begin{cases}{\left[\begin{array}{ll}
1-\frac{a / b}{A / B} &
\end{array}\right] \cdot \frac{100 \cdot k}{C V \%},} & \text { for } A / B<a / b \\
0, & \text { for } A / B=a / b \\
{\left[\frac{A / B}{a / b}-1\right] \cdot \frac{100 . k}{C V \%},} & \text { for } A / B>a / b\end{cases}
$$

Elwali \& Gascho (1984):

$$
f(A / B)= \begin{cases}{\left[1-\frac{a / b}{A / B}\right] \cdot \frac{100 \cdot k}{C V \%},} & \text { for } A / B<a / b-s \\ 0, & \text { for } a / b-s \leq A / B \leq a / b+s \\ {\left[\frac{A / B}{a / b}-1\right] \cdot \frac{100 \cdot k}{C V \%},} & \text { for } A / B>a / b+s\end{cases}
$$

Jones (1981):

$$
\mathrm{f}(\mathrm{A} / \mathrm{B})=(\mathrm{A} / \mathrm{B})-\mathrm{a} / \mathrm{b}) \mathrm{k} / \mathrm{s}
$$

where: $\mathrm{A} / \mathrm{B}=$ relation between the concentration of the nutrient $A$ and $B$ in the sample; $a / b=$ relation between the concentration of the nutrient $\mathrm{A}$ and $\mathrm{B}$ in the reference population; $\mathrm{CV} \%=$ coefficient of variation for the relation, \%; $\mathrm{s}=$ standard deviation in the relation; $\mathrm{k}=$ constant of sensibility.

The Nutritional Balance Index (NBI) was calculated through the sum of the absolute values of the indices generated for the sample, obtained for each nutrient of each orchard, according to the equation:

$$
\mathrm{NBI}=|\operatorname{Index} \mathrm{A}|+|\operatorname{Index} \mathrm{B}|+\ldots .+|\operatorname{Index} \mathrm{N}|
$$

The Mean Nutritional Balance Index (NBIm) was also obtained through the sum of the absolute values of the indices generated for each nutrient, calculated for each sample, divided by the number of nutrients that participate in the calculation, according to:

$\mathrm{NBIm}=(|\operatorname{Index} \mathrm{A}|+|\operatorname{Index} \mathrm{B}|+\ldots .+|\operatorname{Index} \mathrm{N}|) / \mathrm{N}$ 
To evaluate the efficiency of the DRIS method in the nutritional diagnosis of the apple crop, the results of a field experiment of of long duration were used, carried out in Vacaria RS $\left(28^{\circ} 30^{\prime} 00^{\prime \prime} \mathrm{S}\right.$ and $50^{\circ} 42^{\prime} 21^{\prime \prime} \mathrm{W}$ and $955 \mathrm{~m}$ above sea level), on a Humic Xanthic Hapludox (Latossolo Bruno alumínico câmbico (Streck et al., 2002)), using virus free seedlings of the cultivar Gala grafted on MM 106 rootstock, in a spacing of $2.5 \times 5.0 \mathrm{~m}$. The treatments consisted of three levels of potassium fertilization before plantating $(0$ $50-100 \mathrm{~kg} \mathrm{ha}^{-1}$ of $\mathrm{K}_{2} \mathrm{O}$ ) and four levels of annual maintenance potassium fertilization $(0-50-100-150 \mathrm{~kg}$ $\mathrm{ha}^{-1}$ of $\mathrm{K}_{2} \mathrm{O}$ ). The experimental design consisted of was the randomized blocks with four replicates. The experiment was maintained for 12 years (1990 to 2001).

The diagnosis or evaluation of the foliar concentration of nutrients for the apple tree crop was accomplished using the Range of Nutrients Concentration Criterion, adopted in Rio Grande do Sul and Santa Catarina States, Brazil, and by DRIS, through the three methods here presented. The consistence of the diagnosis was tested through the comparison among these three diagnosis criteria. For the Range of Nutrients Concentration Criterion, only three categories were used (deficiencient, normal, and in excess). For the nutritional diagnosis using the DRIS method, the used methodology was that proposed by Wadt (1996), also useing three ranges, established from the DRIS index of the nutrient $\left(\mathrm{I}_{\mathrm{Nut}}\right.$. $)$ and of the Mean Nutritional Balance Index (NBIm), assuming:

$$
\begin{array}{lll}
\text { Deficient }=\mathrm{I}_{\text {Nut. }}<0 \quad \text { and } & \left|\mathrm{I}_{\text {Nut. }}\right|>\text { NBIm } \\
\text { Normal }=\left|\mathrm{I}_{\text {Nut. }}\right| \leq \text { NBIm } & & \\
\text { In excess }=I_{\text {Nut. }}>0 \quad \text { and } & \left|\mathrm{I}_{\text {Nut. }}\right|>\text { NBIm }
\end{array}
$$

The calculations of the DRIS indices, NBI and NBIm were made through the software Microsoft Excel $^{\mathrm{TM}}$. To evaluate the efficiency of the three methods, considering the two criteria of for the choice of the ratio order of nutrients, NBI was related to the productivity of fruits and verified the significance of the correlation, using the "General Linear Models" (GLM) of the SAS statistical package (SAS Institute, 1985).

\section{RESULTS AND DISCUSSION}

The relations between NBI and the productivity for the reference population and for the population of low productivity (Figure 1) indicate that the correlation coefficients obtained for the reference population were significant, while the relationship was not significant for the population of low productivity. Considering the whole population, the relationship is coherent with the expected results (Sumner, 1977), with the productivity varying from high to low for low values of NBI, while high values of NBI occurred only in cases of low productivity.

The correlation coefficient between NBI and the productivity for the reference population, although statistically significant, were low, varying from 0.12 to 0.17 . This behavior is probably related to the fact that in this type relation (NBI $\times$ production) participated only plants of medium to high productivity. These plants should at first present nutritional balance, so that the variation of the productivity would be more dependent on other non nutritional factors. Relations between NBI and the productivity with accentuated dispersion of points, originating relatively low values of $\mathrm{R}^{2}$, were also obtained by Wadt et al. (1998) for eucalyptus and for Wadt et al. (1999) for coffee, in studies to generate the DRIS norms for these crops. In both cases, high values of NBI occurred only in cases of low productivity, a fact that was also observed for the apple tree crop.

Comparing the combinations of criteria of choice of ratio among nutrients ( $\mathrm{R}$ value and $\mathrm{F}$ value) and of methods of calculation of the DRIS indices, it was observed that the best adjustments between NBI and productivity for the reference population were obtained by the method of Jones, using the $\mathrm{F}$ value and for the method of Elwali \& Gascho, using the F and $\mathrm{R}$ values. Working with citrus in the State of São Paulo, Santos (1997) verified superiority of the method of Jones over the other. These results were also observed by Nick (1998) for the coffee plant and for Mourão Filho \& Azevedo (2003) for the 'Valency'orange tree. Regarding the criterion of the choice of ratio order among the nutrients, Nick (1998) and Mourão Filho et al. (2002) observed that the criterion of $\mathrm{R}$ was superior to $\mathrm{F}$. There are no studies for the apple tree crop on the comparison of methods and of criteria of choice of ratio of nutrients. Singh et al. (2000) used for the evaluation of the DRIS method for apple trees in India, the method proposed by Beaufils (1973) and the criterion of the largest ratio among variances between the populations of low and high productivity ( $\mathrm{F}$ value).

Figure 2 presents the relation among the relative production of fruits of apple tree $\mathrm{cv}$. Gala and the NBI, as a function of the rates of potassium fertilizer. NBI presented a behavior close to the theoretical model, with an adjustment according to a quadratic model and inverse relation to the production of fruits. The correlations were significant $(P<0.01)$, indicating that the DRIS methods were efficient in the evaluation of the nutritional status of the crop, with exception to the method of Jones (1981), using F with high productions observed along high values of NBI. In general, 

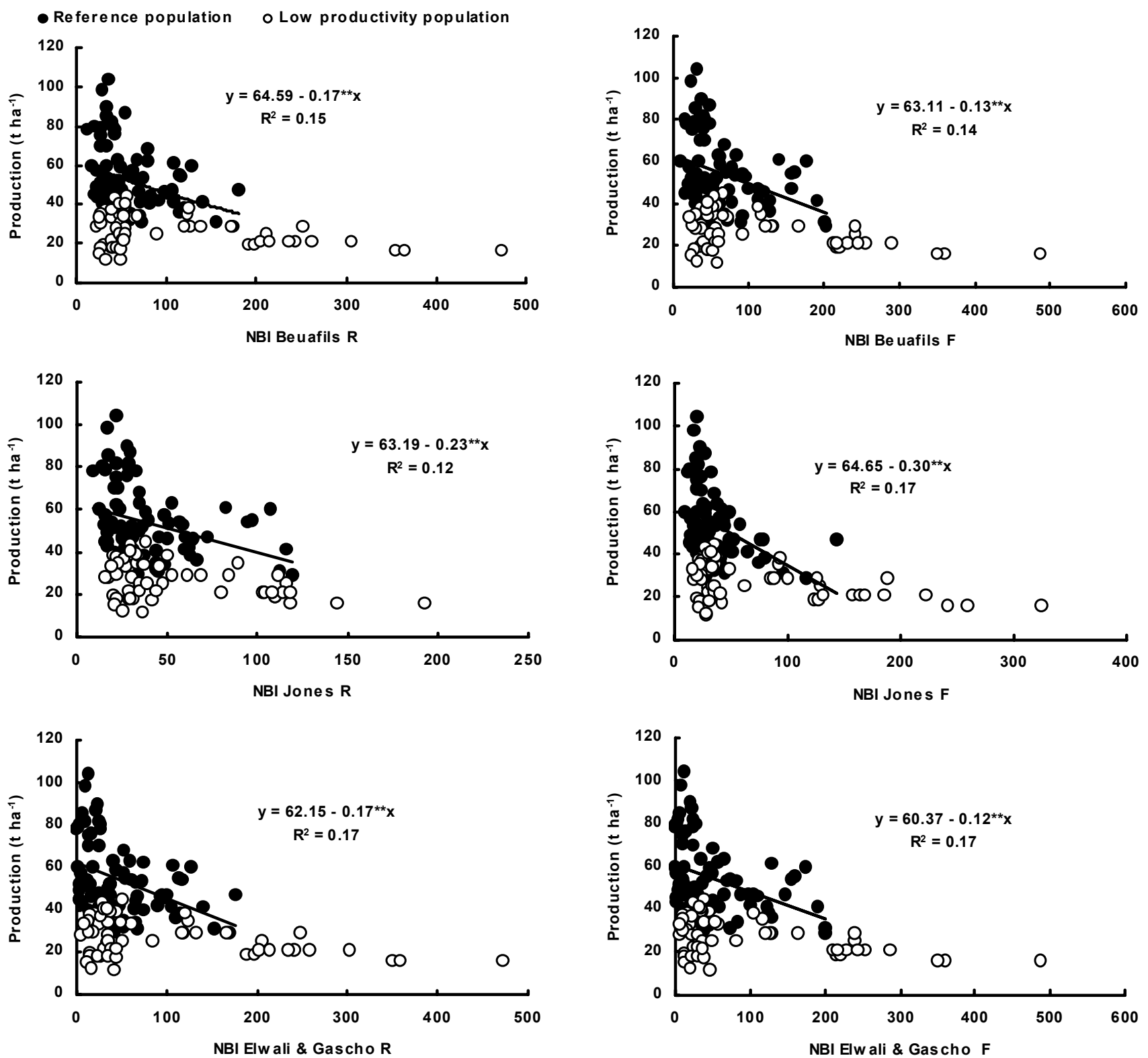

Figure 1 - Relation between the values of Nutritional Balance Index (NBI) and the productivity $\left(\mathrm{t} \mathrm{ha}^{-1}\right)$ for combinations of methods of ratio choice among nutrients ( $\mathrm{R}$ value and F value) and DRIS indices (methods Beaufils, Jones and Elwali \& Gascho) for the reference population and for the population of low productivity.

the largest productivities were related to the smallest values of NBI. For this situation, in which the productivity was influenced by the nutritional status of the plants, specifically for the potassium availability, the adjustment between NBI and the productivity presented much higher values of correlation coefficients than those obtained for the reference population, showing that the larger the nutritional unbalance of the plants (larger value of NBI) the lower is the productivity. A similar result was also obtained by Silva et al. (2003), when evaluating the use of DRIS to establish the nutritional status of the coffee plant in response to potassium fertilization.
For the definition of the best method, the accordance percentage among the DRIS methods and the criterion of sufficiency range for the nutritional diagnosis were verified, considering all the appraised nutrients in the experiment of potassium fertilization. For this, the number of cases for each nutrient, with deficient apporpriate nutrition and excess diagnosis for the criterion of sufficiency range and for the DRIS methods were compared. Bataglia et al. (2001) also used the correct percentage of diagnosis for DRIS in relation to the criterion of sufficiency range, as a form of selecting the population of the reference coffee plant. 

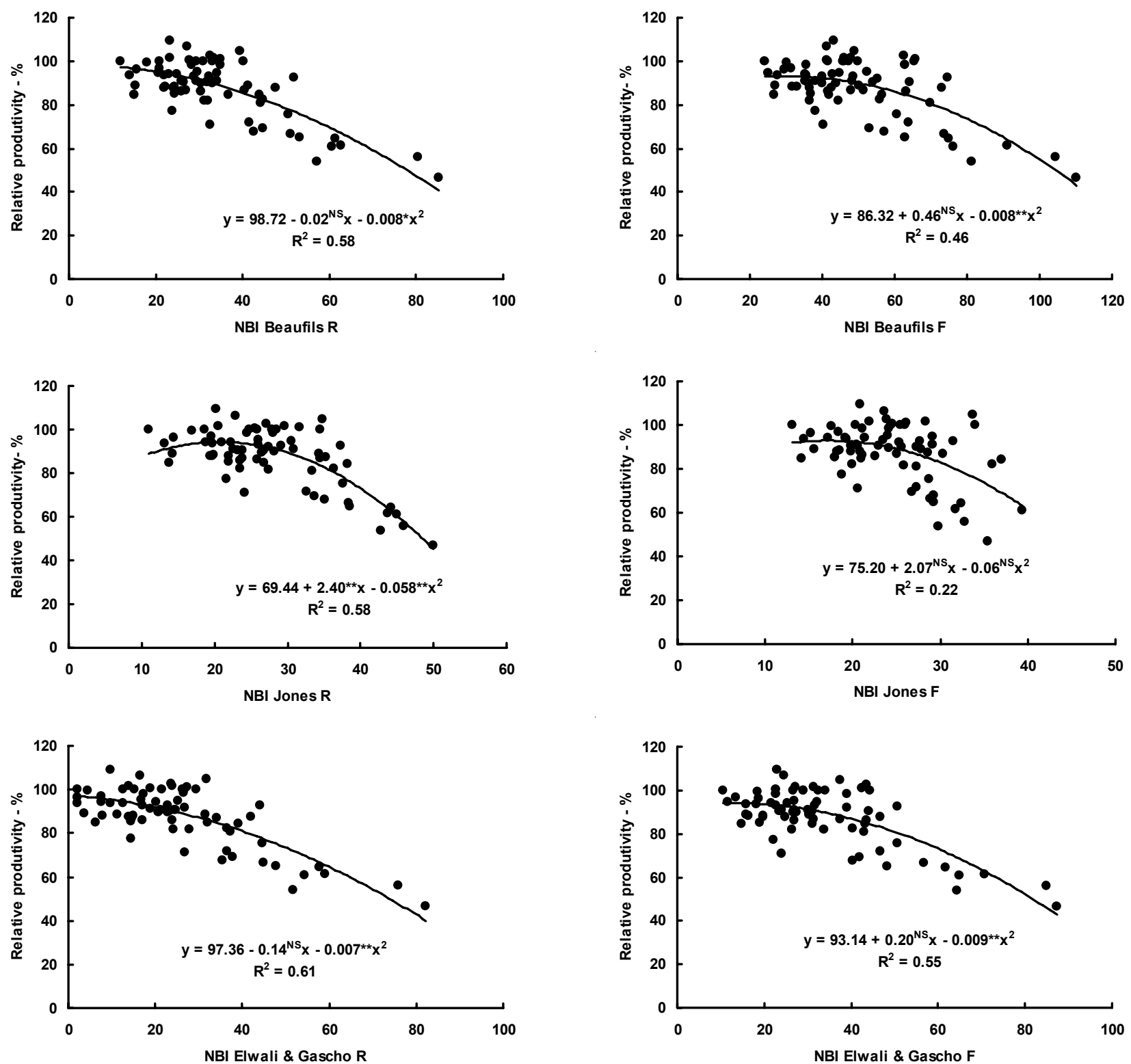

Figure 2 - Relation between the relative production of fruits of the apple tree cv. Gala and the Nutritional Balance Index (NBI) for combinations of methods of ratio order choice among nutrients ( $\mathrm{R}$ value and F value) and DRIS indices (methods Beaufils, Jones and Elwali \& Gascho), as a function of rates of potassium fertilizer. (Six years-old results)

For the diagnosis regarding $\mathrm{K}$, the element that presented the largest variation among the results due to the applied rates, the accordance percentage in the nutritional diagnosis varied from $62 \%$ to $78 \%$ for the appraised models (Table 1). When all the nutrients were considered, the largest accordance number was observed when the method Elwali \& Gascho was used, using the $\mathrm{F}$ criterion. In addition, the other methods presented low accordance with the criterion of sufficiency range for $\mathrm{P}, \mathrm{Ca}$ and $\mathrm{Zn}$. For $\mathrm{P}$ and $\mathrm{Ca}$, the criterion of sufficiency range identified a larger number of deficient samples than the methods Beaufils and Jones, while for $\mathrm{Zn}$ these methods identified a larger number of samples with excess, than the criterion of sufficiency range.

Comparing the mean results obtained by the two criteria of choice of the ratio order of nutrients ( $\mathrm{F}$ and $\mathrm{R}$ values), it was verified that the largest accordance percentage in the nutritional diagnosis of the apple tree (deficient, normal and in excess), between the criterion of sufficiency strip and the DRIS methods, was obtained when the F criterion was used, indicating it as the most appropriate criterion for the crop. These results differ from the those obtained by Nick (1998) and Mourão Filho et al. (2002). They observed that the criterion of $\mathrm{R}$ was better than $\mathrm{F}$. 
Table 1 - Accordance percentage in the nutritional diagnosis of the apple tree (deficient, normal and in excess) between the Range of Nutrients Concentration Criterion and the methods DRIS for combinations of criteria of choice of the ratio order among nutrients ( $\mathrm{R}$ value and $\mathrm{F}$ value) and DRIS indices (methods Beaufils, Jones and Elwali \& Gascho), as a function of rates of potassium fertilizer. (Six year-old results)

\begin{tabular}{|c|c|c|c|c|c|c|}
\hline \multirow{2}{*}{ Nutrient } & \multicolumn{2}{|c|}{ Beaufils } & \multicolumn{2}{|c|}{ Jones } & \multicolumn{2}{|c|}{ Elwali \& Gascho } \\
\hline & $\mathrm{R}$ & $\mathrm{F}$ & $\mathrm{R}$ & $\mathrm{F}$ & $\mathrm{R}$ & $\mathrm{F}$ \\
\hline & (- & - & . & 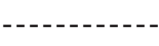 & -1 & \\
\hline $\mathrm{N}$ & 62.50 & 70.83 & 55.56 & 68.06 & 50.00 & 73.61 \\
\hline $\mathrm{P}$ & 43.06 & 68.06 & 51.39 & 58.33 & 45.83 & 81.94 \\
\hline $\mathrm{K}$ & 77.78 & 65.28 & 75.00 & 62.50 & 73.61 & 70.83 \\
\hline $\mathrm{Ca}$ & 43.06 & 59.72 & 47.22 & 50.00 & 37.50 & 70.83 \\
\hline $\mathrm{Mg}$ & 54.17 & 80.56 & 58.33 & 68.06 & 63.89 & 63.89 \\
\hline $\mathrm{Fe}$ & 76.39 & 86.11 & 81.94 & 97.22 & 97.22 & 95.83 \\
\hline $\mathrm{Mn}$ & 100.00 & 100.00 & 100.00 & 100.00 & 100.00 & 100.00 \\
\hline $\mathrm{Zn}$ & 19.44 & 0.00 & 8.33 & 8.33 & 38.89 & 94.44 \\
\hline $\mathrm{Cu}$ & 77.78 & 81.94 & 83.33 & 54.17 & 91.67 & 93.06 \\
\hline B & 83.33 & 87.50 & 83.33 & 84.72 & 80.56 & 81.94 \\
\hline Average & 63.75 & 70.00 & 64.44 & 65.14 & 67.92 & 82.64 \\
\hline
\end{tabular}

The method of Elwali \& Gascho, using the F criterion is the most suitable for the apple tree crop, presenting values of NBI that indicate the nutritional status of the plants and for the efficiency in the nutritional diagnosis of the crop.

\section{CONCLUSIONS}

The Nutritional Balance Index (NBI), calculated from the generated norms, presented negative correlation with the productivity for all of the combinations of the tested methods. The DRIS method described by Elwali \& Gascho, using the F value, presented similar performance in relation to the criterion of sufficiency range. The DRIS method can be used for the interpretation of foliar analysis for the apple tree, for presenting values of NBI that indicate the nutritional status of the plants and for the efficiency in the nutritional diagnosis of the crop.

\section{REFERENCES}

BATAGLIA, O.C.; SANTOS, W.R.; QUAGGIO, J.A. Reference populations for evaluation of the nutritional status of coffee by DRIS. In: HORST, W.J.; SCHENK, M.K.; BÜRKERT, A.; CLAASSEN, N.; FLESSA, H.; FROMMER, W.B.; GOLDBACH, H.; OLFS, H.W.; RÖMHELD, V.; SATTELMACHER, B.; SCHMIDHALTER, U.; SCHUBERT, S.; WIRÉN, N.V.; WITTENMAYER L. (Ed.). Plant nutrition - Food security and sustainability of agro-ecosystems. Dordrecht: Kluwer Academic Publishers, 2001. p.728-729.

BEAUFILS, E.R. Physiological diagnosis - a guide for improving maize production based on principles developed for rubber trees. Fertilizer Society of South African Journal, v.1, p.1-30, 1971.
BEAUFILS, E.R. Diagnosis and recommendation integrated system (DRIS). A general scheme for experimentation and calibration based on principles developed from research in plant nutrition. Pietermararitzburg: University of Natal, 1973. 132p. (Soil Science Bulletin, 1).

ELWALI, A.M.O.; GASCHO, G.J. Soil testing, foliar analysis, and DRIS as guide for sugarcane fertilization. Agronomy Journal, v.76, p.466-470, 1984.

FAUST, M. Physiology of temperate zone fruit trees. New York: John Wiley. 1989. 338p.

GOH, K.M.; MALAKOUTI, M.J. Preliminary nitrogen, phosphorus, potassium, calcium and magnesium DRIS norms and indices for apple orchards in Canterbury, New Zealand. Communications in Soil Science and Plant Analysis, v.23, p.1371-1385, 1992.

JONES, C.A. Proposed modifications of the diagnosis and recommendation integrated system (DRIS) for interpreting plant analysis. Communications in Soil Science and Plant Analysis, v.12, p.785-794, 1981.

LETZSCH, W.S. Computer program for selection of norms for use in the diagnosis and recommendation integrated system (DRIS). Communications in Soil Science and Plant Analysis, v.16, p.339-347, 1985.

MOURÃO FILHO, F.A.A.; AZEVEDO, J.C. DRIS norms for 'Valencia' sweet orange on three rootstocks. Pesquisa Agropecuária Brasileira, v.38, p.85-93, 2003.

MOURÃO FILHO, F.A.A.; AZEVEDO, J.C.; NICK, J.A. Funções e ordem da razão dos nutrientes no estabelecimento de normas DRIS em laranjeiras 'Valência'. Pesquisa Agropecuária Brasileira, v.37, p.185-192, 2002.

NACHTIGALL, G.R.; DECHEN, A.R. DRIS norms for evaluating the nutritional state of apple tree. Scientia Agricola, v.64, p.282-287, 2007.

NICK, J.A. DRIS para cafeeiros podados. Piracicaba: USP/ESALQ, 1998. 86p. (Dissertação - Mestrado).

PARENT, L.E.; GRANGER, R.L. Derivation of DRIS norms for a high density apple orchard established in the Quebec Appalachian mountains. Journal of the America Society for Horticultural Science, v.114, p.915-919, 1989.

SANTOS, W.R. Métodos diagnósticos do equilíbrio nutricional dos macronutrientes em citros. Piracicaba: USP/ESALQ, 1997. 113p. (Dissertação - Mestrado). 
SAS INSTITUTE. SAS User's guide: statistics. 5 ed. Cary, N.C., 1985. 956 p.

SILVA, E.B.; NOGUEIRA, F.D.; GUIMARÃES, P.T.G. Uso do DRIS na avaliação do estado nutricional do cafeeiro em resposta à adubação potássica. Revista Brasileira de Ciência do Solo, v.27, p.247-255, 2003.

SINGH, N.P.; AWASTHI, R.P.; SUD, A. Diagnosis and recommendation integrated system (DRIS) norms for apple (Malus x Domestica Borkh. L. CV. Starking Delicious) in Himachal Pradesh. Indian Journal of Horticulture, v.57, p.196-204, 2000.

STRECK, E.V.; KÄMPF, N.; DALMOLIN, R.S.D.; KLAMT, E.; NASCIMENTO, P.C.; SCHNEIDER, P. Solos do Rio Grande do Sul. Porto Alegre: EMATER/RS; UFRGS, 2002. 107p.

SUMMER, M.E. Use of the DRIS system in foliar diagnosis of crops at high yield levels. Communications in Soil Science and Plant Analysis, v.8, p.251-268, 1977.

SZÜCS, E.; KÁLLAY, T. Determination of fruiting capacity of apple trees (Malus domestica) by DRIS. In: INTERNATIONAL PLANT NUTRITION COLLOQUIUM, 11., Wageningen, 1989. Annals. Dordrecht: Kluwer Academic Publishers, 1990. p.717721.
SZÜCS, E.; KÁLLAY, T.; SZENCI, G. Determination of DRIS indices for apple (Malus domestica Borkh). Acta Horticulturae, n.274, p.443-453, 1990.

WADT, P.G.S. Os métodos da chance matemática e do sistema integrado de diagnose e recomendação (DRIS) na avaliação nutricional de plantios de eucalipto. Viçosa: UFV, 1996. 123p. (Tese - Doutorado).

WADT, P.G.S.; NOVAIS, R.F.; ALVAREZ VENEGAS, V.H.; FONSECA, S.; BARROS, N.F. Valores de referência para macronutrientes em eucalipto obtidos pelos métodos DRIS e chance matemática. Revista Brasileira de Ciência do Solo, v.22, p.685-692, 1998.

WADT, P.G.S.; NOVAIS, R.F.; ALVAREZ VENEGAS, V.H.; BRAGANÇA, S.M. Alternativas de aplicação do "DRIS" à cultura de café conilon (Coffea canephora Pierre). Scientia Agricola, v.56, p.83-92, 1999.

WALWORTH, J.L.; SUMMER, M.E. The diagnosis and recommendation integrated system (DRIS). Advances in Soil Science, v.6, p.149-188, 1987.

Received June 08, 2005

Accepted April 13, 2007 